\title{
Use of three types of walkers: impact on the functional performance profile of institutionalized older adults
}

Uso de três tipologias de um andarilho: impacto no perfil de desempenho funcional de idosos institucionalizados

Uso de tres tipologías de andador: impacto en el perfil del desempeño funcional de las personas mayores institucionalizadas

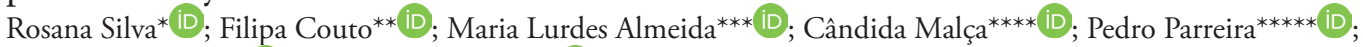
João Apóstolo***** (D); Arménio Cruz ${ }^{* * * * * * *(D)}$

\section{Abstract}

Background: Aging is associated with acute and chronic problems that interfere with older adults' mobility and independence. There are several types of walkers available in the market with different functional performance profiles of older people which aim to compensate for physical limitations and prevent falls.

Objective: To compare the functional performance profile of institutionalized older adults taking into account the total time, gait speed, heart rate variability, and energy cost during the Expanded Timed Get-up-and-Go test using three types of walkers: fixed, two-wheeled, and four-wheeled walkers.

Methodology: One-group pretest and posttest quasi-experimental study in a convenience sample of 40 institutionalized older people.

Results: Significant differences were found in the total time $\left(X^{2}=15.65 ; p<0.001\right)$ and gait speed $\left(X^{2}=15.80, p<0.001\right)$. Conclusion: There is no unique ideal solution among the types of walkers analyzed in this study, thus a tailored solution is desirable to meet institutionalized older adults' characteristics and specific needs.

Keywords: aged; equipment and supplies; walker; functional performance profile; rehabilitation nursing

\section{Resumo}

Enquadramento: Ao envelhecimento associam-se problemas agudos e crónicos que interferem com a mobilidade da pessoa idosa e a sua independência. Atualmente, existem no mercado diversas tipologias de andarilho com diferentes perfis de desempenho funcional do idoso, que visam compensar limitaçôes físicas e prevenir quedas.

Objetivo: Comparar o perfil de desempenho funcional de pessoas idosas institucionalizadas tendo em conta o tempo percorrido, velocidade de marcha, variância frequência cardíaca e custo energético despendido aquando da realização do teste Expanded Timed Get-up-and-Go no uso de três tipologias de um andarilho: fixo, duas rodas e quatro rodas.

Metodologia: Estudo quasi-experimental antes e após de grupo único, numa amostra de conveniência de 40 pessoas idosas institucionalizadas.

Resultados: Foram identificadas diferenças significativas no tempo percorrido $\left(X^{2}=15,65 ; p<0,001\right)$ e na velocidade de marcha $\left(X^{2}=15,80 ; p<0,001\right)$.

Conclusão: Não existe uma soluçáo ideal única entre as tipologias do andarilho analisadas, sendo, portanto, desejável uma solução personalizada às características e necessidades da pessoa idosa institucionalizada.

Palavras-chave: idoso; dispositivo auxiliar de marcha; andarilho; perfil de desempenho funcional; enfermagem em reabilitação

*MSc., Rehabilitation Nurse, Nursing School of Coimbra, 3046-851, Coimbra, Portugal [rosanamisilva82@ gmail.com. (D hittps://orcid.org/0000-0001-7603-8148. Contribution to the article: study design; methodological planning: data collection, treatment and analysis; article witing Address for correspondence: Rua do Chafariz, $1^{\circ}$ E frente, $n^{\circ} 152,3045-199$, Coimbra, Portugal

**RN., UICISA: E Research grant holder, Nursing School of Coimbra, 3046-851, Coimbra, Portugal fflipadecouto@esenfcpt]. D https://orcidory 0000-0002-9895-3592. Contribution to the article: article writin study design; methodological supervision; article revision.

***Ph.D. UICISA: E Researcher and Coordinating Professor, Nursing School of Coimbm 3046-851, Coimbra, Portugal [mlurdes@ $a$ esenfc.pt]. (D) https://orcid.ory/0000-000244548743. Contribution to the article methodological supervision, article revision.

****Ph.D., Adjunct Professor of the Department of Mechanical Engineering of the Coimbra Institute of Engineering Vice-President of the Polvtechnic Institute of Coimbra, 3030-199, Coimbra. Portugal [candid malca@ipc.pt]. (D) https://orcid.org0000-0003--0012-4380. Contribution to the article: methodological supervision, article revision

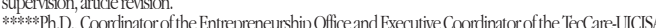
E axis. UTCISA: E Researcher and Coordinating Professor: Nursing School of Coimbra, 3046-851, Coimbm

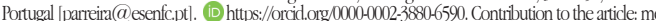

thodological planning; study design; methodological supervision; article revision. Coimbra, Portugal [apostolo@esenf..pt]. (1) https://orcid.org/0000-0002-3050-2264. Contribution to the article: methodological planning; study design; methodological supervision; article revision

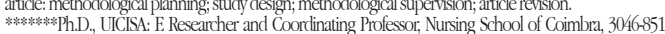
Coimbra, Portugal [acruz@esenfcpt. (D https://orcid.org/0000-0003-32543176. Contribution to the artide: methodological planning; study design; methodological supervision; article revision.

\section{Resumen}

Marco contextual: El envejecimiento está asociado con problemas agudos y crónicos que interfieren en la movilidad de la persona mayor y su independencia. En la actualidad, existen en el mercado varios tipos de andadores con diferentes perfiles de rendimiento funcional de las personas mayores, que tienen como objetivo compensar las limitaciones físicas y prevenir las caídas.

Objetivo: Comparar el perfil de rendimiento funcional de las personas mayores institucionalizadas teniendo en cuenta el tiempo recorrido, la velocidad de la marcha, la variancia de la frecuencia cardíaca y el coste energético gastado durante la prueba Expanded Timed Get-up-and-Go en el uso de tres tipologías de andador: fijo, de dos ruedas y de cuatro ruedas.

Metodología: Estudio cuasiexperimental antes y después de un solo grupo, en una muestra de conveniencia de 40 personas mayores institucionalizadas.

Resultados: Se identificaron diferencias significativas en el tiempo recorrido $\left(X^{2}=15,65 ; p<0,001\right)$ y en la velocidad de la marcha $\left(X^{2}=15,80 ; p<0,001\right)$.

Conclusión: No existe una única solución ideal entre las tipologías de andador analizadas, por lo que lo mejor es una solución personalizada a las características y necesidades de la persona mayor institucionalizada.

Palabras clave: anciano; equipos y suministros; andador; perfil de desempeño funcional; enfermería en rehabilitación 


\section{Introduction}

Societies are currently facing the sociodemographic trend of aging. According to data from Statistics Portugal (Instituto Nacional de Estatística [INE]) on this global phenomenon, in Portugal, the number of older people will increase from 2.1 in 2015 to 2.8 million in 2080 and the aging index will increase from 147 to 317 older people for every 100 young people in the same time period (INE, 2017). This sociodemographic trend is accompanied by an increase in the number of institutionalized older people. In addition to this phenomenon, older people are more prone to a rapid deterioration of functional capacity as a result of the multiple chronic-degenerative diseases that affect their autonomous and independent lives. With this decline, there is a growing need for assistive gait devices to promote older people's mobility and increase their independence and functionality, thus promoting their safety (Maria \& Rodrigues, 2009).

Walkers are assistive gait devices that promote balance and reduce lower limb loads partially or in full (Poier, 2013). As a result of innovation and development studies, the market offers several types of walkers for older people with specific functional needs which incorporate new technologies and materials.

However, there are reports of falls while using this type of device, either due to a poor adaptation of the walker to the user's specific needs, or to inadequate use/maintenance. Given the increasing number of users, it is important to study factors related to user protection based on older people's functional capabilities or functional performance profile (Braun, Marks, Zutter, \& Grüneberg, 2015).

In Portugal, the rehabilitation clinical nurse specialist (enfermeiro especialista em enfermagem de reabilitação, EEER) can be integrated into the healthcare team. These nurses' competencies are essential for the prevention of functional decline and the promotion of autonomy in people with limited mobility. Whenever necessary, these nurses can prescribe assistive gait devices, such as walkers. As a specialized health professional, the EEER must, therefore, participate in the development of health research and innovation projects, which contribute to promoting both the autonomy and quality of life of people with functional impairment (Regulamento . $^{\circ}$ 125/2011 de 18 de fevereiro, 2011).

In this context, this study aims to compare the functional performance profile of institutionalized older people taking into account the total time, gait speed, heart rate variability, and energy cost during the Expanded Timed Get-up-and-Go (ETGUG) test using three types of walkers: fixed, two-wheeled, and four-wheeled walkers. The study was developed within the scope of the research activities of the project MIND\&GAIT - Promoting independent living in frail older adults by improving cognition and gait ability and using assistive products - which includes the improvement of a prototype of a self-locking mechanism for walker wheels. The prototype resulted from the collaboration between three fields of scientific knowledge - mechanical engineering, electromechanical engineering, and rehabilitation nursing - and was developed based on the following basic principle: to prevent and significantly reduce the risk of falls, thus increasing safety in older people's mobility.

\section{Background}

According to the literature, aging is a key phenomenon in the development of new geriatric syndromes and is responsible for a progressive vulnerability of the occurrence of adverse health events such as falls or fractures, especially in individuals with underlying chronic diseases (Mota de Sousa et al., 2016).

In addition to the lack of activity, which is sometimes inherent to this physiological process, there is also a decrease in muscle activity and, consequently, a loss of muscle tissue, which translates into a less efficient sensorimotor coordination, increased difficulties of adaptation to new situations and/or technical aids, and loss of balance (Lobo, 2012). These changes contribute to a loss of static and dynamic balance which leads to a progressive decline in mobility and increased fall risk. Inevitably, older people are faced with changes in their gait speed, heart rate, and energy cost, especially while using assistive gait devices that are not adapted to their specific conditions.

These changes, together with the loss of physical strength, reduce older people's capacity to 
adapt to the environment and increase their vulnerability to the pathological processes that interfere with their functional performance, competence, and capacity, thus reducing their quality of life (Sousa et al., 2014).

Therefore, assistive gait devices are used because they enhance balance, reduce lower limb loads, and, consequently, alleviate joint pain, reducing fatigue and compensating for weakness (Cheng et al., as cited in Teresa, 2014).

Standard walkers are classified depending on the type of contact with the floor and may have four tips or fixed wheels, two front wheels or four wheels (Lacey \& Dawson-Howe, as cited in Teresa, 2014). Fixed walkers have four legs with rubber tips. Despite being the most stable walkers, they require users to have more motor control to pick the walker completely off the ground and place it forward before stepping forward. This results in a slower, controlled gait pattern, requiring some strength in the upper limbs (Teresa, 2014).

Front-wheeled walkers are suitable for users who have more weakness in the upper limbs, thus more difficulty in lifting the fixed walker, or backward imbalance while lifting this device (Van Hook, Demonbreun, \& Weiss, 2003). They are best for people with a faster gait because they promote a forward displacement of the center of gravity, reducing the risk of falling backward (Lacey \& Dawson-Howe, as cited in Teresa, 2014). According to Teresa (2014), this is the most common device and allows a more normal gait, as the person does not need to stop.

Four-wheeled walkers are recommended for people who require a larger base of support and do not rely on the walker to bear weight. This type of walker is not recommended for people with balance problems and/or cognitive impairment given that it can unexpectedly roll away, resulting in a fall. The wheel system facilitates its use because it does not need to be lifted for the patient to move forward, requiring minimal user effort (Teresa, 2014). They are the best devices for higher functioning patients who walk long distances with minimal weight bearing (Van Hook et al., 2003). However, they can increase the risk of falling if there are objects in the surrounding environment due to the difficulty of navigating with obstacles or in tight spaces (Priebe \& Kram, as cited in
Teresa, 2014).

In these last two models, a self-locking kit for both front wheels was recently developed to provide a braking system in case of backward imbalance and allow for safer ambulation (Parreira, 2013). This system is integrated into the walker used in this study.

The structure of these standard walkers can cause imbalance, posing safety issues. Therefore, their prescription should depend on several protective factors such as the user's functional performance profile, balance, and fall risk. These factors are associated with gait characteristics, namely speed indicators, heart rate, and the physiological cost index (PCI; Walter et al., as cited in Cetin, Muzembo, Pardessus, Puisieux, \& Thevenon, 2010).

Integrated in a multidisciplinary team and in view of their expertise, EEERs assess the needs of people with mobility limitations based on the abovementioned functional profile indicators and calculate the PCI with a view to promoting their adaptive capacity in processes of disease/ health transition and/or disability, as well as the necessary safety measures for a safe ambulation, including the selection and prescription of assistive gait devices, whenever necessary.

\section{Hypothesis}

There are differences in the functional performance profile of institutionalized older people taking into account the total time, gait speed, heart rate variability, and energy cost during the ETGUG test using three types of walkers: fixed, two-wheeled, and four-wheeled walkers.

\section{Methodology}

A one-group pretest and posttest quasi-experimental study was conducted in a convenience sample of institutionalized older people who used walkers on a regular basis $(N=40)$. These participants were selected from five residential structures for elderly people (Estruturas Residenciais para Idosos, ERPI) in the geographical area of Coimbra and met the inclusion and exclusion criteria. Inclusion criteria: i) older person aged $\geq 65$ years who used a walker on a regular basis; ii) hemodynamically stable (systolic/ 
diastolic blood pressure $<150 / 100 \mathrm{mmHg}$ ); and (iii) who gave their informed consent to participate in this study. Exclusion criteria: i) pain greater than or equal to 3 (moderate to intense) - assessed using the Numerical Pain Rating Scale (Likert, 0-10 points); ii) history of orthopedic surgery to the upper and/or lower limbs in the past 3 months.

Data were collected between April and May 2018, after obtaining the favorable opinion of the Ethics Committee of the Health Sciences Research Unit: Nursing (UICISA: E) for study development (No. 489_03-18) and authorization of the board of directors of each ERPI, as well as the participants' informed consent. Data were collected through a semi-structured interview with a questionnaire designed by the research team for this purpose and an evaluative test for collection of indicators. In the interview, sociodemographic data were collected, as well as data on the levels of functionality as measured by the Barthel Index and the walkers used on a regular basis.

The variables in the research protocol were collected in person. The walker (fixed, twowheeled, and four-wheeled) was adapted to the older person during the pretest, which lasted for approximately 2 to 5 minutes. The protocol includes the completion of the ETGUG test, following the guidelines of Cetin et al. (2010), with the three types of INVACARE ${ }^{\bullet}$ walkers, reference $6291 \mathrm{E}-\mathrm{A}$, with an aluminum frame, height-adjustable, and an approximate weight of $3 \mathrm{~kg}$ (four tips, two wheels and four wheels, with the former two having a self-locking kit). The ETGUG test consists of using the three types of walkers in a pre-established 10 -meter walk in the ERPI where the older person lives, without a pre-set time. An armless chair with a seat height of about $46 \mathrm{~cm}$ was used in the test. The chair was positioned with the back legs placed at the start of the walkway. From this point, colored tape was placed on the floor at 2, 8, 9, and $10 \mathrm{~m}$ distances. The final meter was marked as a box, which indicated the area in which the subjects are asked to turn around. During the ETGUG test, in each type of walker, the heart rate (HR) was measured using a Contec $^{\oplus}$ pulse monitor, model CMS50N, at the beginning and end of the test, and the total time of the test was assessed using a Kalenji ${ }^{\oplus}$ chronometer. Gait speed (S) was calculated from the expression: $S=$ distance on foot (in meters) $\times 60 /$ time in seconds. After this, the energy cost was calculated using the PCI as used in the study of Cetin et al. (2010). The PCI was calculated using the expression: PCI $=\mathrm{HR}$ (beats per minute) $-\mathrm{HR}$ (rest in beats per minute) / $S$ (in meters per minute).

Data were processed using IBM SPSS Statistics for Windows, version 25.0. Descriptive statistics (e.g., frequency tables, measures of central tendency and measures of dispersion, and inferential statistics) were used to analyze the relationship between the main variables. Friedman tests were used to assess any differences between the walkers, and Wilcoxon tests with Bonferroni correction were used to identify any significant differences between the walkers. A significance level of 0.05 was used.

\section{Results}

A total of 40 older people institutionalized in ERPI participated in the study. They were aged between 65 and 99 years $(M=84.05$; $S D=8.83)$. Most of them were women $(n=$ $34 ; 85 \%)$, widowed $(n=29 ; 72.5 \%)$, with a moderate degree of dependence assessed using the Barthel Index $(n=26 ; 65 \%)$ and users of fixed walkers on a regular basis $(n=28 ; 70 \%)$, mostly prescribed by family members $(n=14$; 35.0\%; Table 1). 
Table 1

Sociodemographic characterization of the sample

\begin{tabular}{lc}
\hline Variables & Sample \\
$(N=40)$
\end{tabular}

Note. $M=$ mean; $S D=$ standard deviation. 
Table 2 shows that the total time to complete the ETGUG test with the three types of walkers was lower when using the four-wheeled walker (150 seconds), followed by the fixed walker (156.9 seconds) and, finally, the twowheeled walker (176.9 seconds). The final HR values were similar among the three walkers, with the lowest value when using the fixed walker $(82.6 \mathrm{bpm})$ and the highest value when using the four-wheeled walker $(84.2 \mathrm{bpm})$. With regard to gait speed, the mean speed was lower when using the two-wheeled walker (mean: $8.9 \mathrm{~m} / \mathrm{min} . ; S D: \pm 5.0$ ) and higher when using the four-wheeled walker (mean: $11.8 \mathrm{~m} / \mathrm{min} ; S D: \pm 7.2$ ) and the fixed walker (mean: $9.6 \mathrm{~m} / \mathrm{min} ; S D: \pm 4.7$ ). In relation to the energy cost calculated using the PCI on the ETGUG test, a lower mean value was found when using the four-wheeled walker (mean: 1.15; SD: \pm 1.46 ) and a higher mean value when using the two-wheeled walker (mean: 1.32; SD: \pm 1.63 ). An intermediate value was found when using the fixed walker (mean: 1.25; SD: \pm 1.32 ).

Table 2

Characterization of the performance profile of the sample

\begin{tabular}{lcccc}
\hline Walker & Time & Final HR & Gait speed & Energy cost (PCI) \\
& $M \pm S D$ & $M \pm S D$ & $M \pm S D$ & $M \pm S D$ \\
\hline Dimension fixed & $156.9 \pm 80.4$ & $82.6 \pm 16.2$ & $9.6 \pm 4.7$ & $1.25 \pm 1.32$ \\
Dimension two-wheeled & $176.9 \pm 91.5$ & $83.7 \pm 16.6$ & $8.9 \pm 5.0$ & $1.32 \pm 1.63$ \\
Dimension four-wheeled & $150.0 \pm 106.4$ & $84.2 \pm 18.1$ & $11.8 \pm 7.2$ & $1.15 \pm 1.46$ \\
\hline
\end{tabular}

Note. $M=$ mean; $S D=$ standard deviation; $\mathrm{HR}=$ heart rate; $\mathrm{PCI}=$ physiological cost index.

\section{Inferential analysis}

Table 3 shows no statistically significant differences in the PCI with the three walkers $\left(X^{2}=\right.$ $2.177 ; p=0.337)$ or in the final $\operatorname{HR}\left(X^{2}=0.770\right.$; $p=0.680)$. However, significant differences were found in the total time to complete the ETGUG test $\left(X^{2}=15.65 ; p<0.001\right)$ and in gait sped with the three walkers $\left(X^{2}=15.80 ; p<0.001\right)$.

Table 3

Differences in the total time in seconds, gait speed, PCI, and HR in the ETGUG test using the three walkers

\begin{tabular}{lccccc}
\hline & $\begin{array}{c}\text { Fixed walker } \\
\text { Mean rank }\end{array}$ & $\begin{array}{c}\text { Two-wheeled } \\
\text { walker } \\
\text { Mean rank }\end{array}$ & $\begin{array}{c}\text { Four-wheeled } \\
\text { walker } \\
\text { Mean rank }\end{array}$ & $X^{2}$ & $P$ \\
\hline PCI & 2.03 & 2.15 & 1.83 & 2.177 & 0.337 \\
Final HR & 1.91 & 1.99 & 2.10 & 0.770 & 0.680 \\
Total time & 1.93 & 2.48 & 1.60 & 15.65 & $\mathbf{0 . 0 0 0}^{*}$ \\
Gait speed & 2.15 & 1.50 & 2.35 & 15.80 & $\mathbf{0 . 0 0 0}^{*}$ \\
\hline
\end{tabular}

Note. $X^{2}=$ Chi-square; $\mathrm{P}=$ probability of significance; $\mathrm{PCI}=$ physiological cost index; $\mathrm{HR}=$ heart rate; ${ }^{*} p<0.001$.

The Wilcoxon tests, with Bonferroni correction, showed differences between the time to complete the ETGUG test with a fixed walker and a two-wheeled walker $(Z=-2.82 ; p<0.005)$, as well as between the two-wheeled walker and the four-wheeled walker $(Z=-2.80, p<$ $0.005)$. The difference found in this variable was not significant between the fixed walker 
and the four-wheeled walker $(Z=-1.25 ; p=$ $0.211)$. These results show that the time to complete the ETGUG test is higher with the two-wheeled walker than with the fixed walker and the four-wheeled walker. No differences were found in the time to complete the ETGUG test between the fixed walker and the four-wheeled walker.

They Wilcoxon tests with Bonferroni correction were also applied to identify statistically significant differences in the gait speed on the ETGUG test. Differences were found between the gait speed with the fixed walker and the two-wheeled walker $(Z=-2.25$; $p<$ $0.024)$, as well as with the four-wheeled walker $(Z=-2.50 ; p<0.012)$. In addition, differences were found between the two-wheeled walker and the four-wheeled walker $(Z=-4.22, p<0.000)$. The results show that the gait speed is higher with the four-wheeled walker when compared to the fixed walker and the two-wheeled walker, but that the gait speed is lower with the two-wheeled walker than with the fixed walker.

\section{Discussion}

Thus, in relation to the hypothesis set out: There are differences in the functional performance profile of institutionalized older people taking into account the total time, gait speed, heart rate variability, and energy cost during the ETGUG test using three types of walkers: fixed, two-wheeled, and four-wheeled walkers, statistically significant differences were found in the total time to complete the ETGUG test and the gait speed between the three walkers. These differences were found in the total time to complete the ETGUG test with the fixed walker and two-wheeled walker, as well as between the two-wheeled walker and the four-wheeled walker. However, no significant difference was found between the fixed walker and the four-wheeled walker. These data allow us to conclude that the total time to complete the ETGUG test is lower with the fixed walker and the four-wheeled walker than with the two-wheeled walker, which suggests that the task is performed faster with the two-wheeled walker than with the other two options, possibly creating more difficulties in its use.

With regard to the gait speed on the ETGUG test, differences were found between the four-wheeled walker and the other two options, suggesting that the gait speed with the four-wheeled walker is higher than with the other two options, and that the gait speed with the fixed walker is lower than with the two-wheeled walker, creating more difficulties in its use. Despite using a different calculation formula, these data coincide with the results found by Priebe and Kram (as cited in Teresa, 2014), who reported that the use of a fixed walker contributes to an increase of $217 \%$ in energy cost when compared to the gait using other walkers and unassisted walking, because the user must be able to pick the walker completely off the ground and place it forward before stepping forward, resulting in a slower and controlled gait pattern.

Silva (2012) reports that, although the wheels in the articulated walkers can facilitate movement, this aspect requires adequate cognitive skills from the user when compared to the use of the fixed walker. According to Priebe and Kram (as cited in Teresa, 2014), the front-wheeled walker creates more instability with an energy cost of $84 \%$ in unassisted walking, while the four-wheeled walker is easier to use due to the inclusion of a wheel system, leading to an energy cost of $70 \%$ in unassisted walking. Cetin et al. (2010) found differences during the Timed Get-up-and-Go (TGUG) test in the gait speed with the fixed walker versus the two-wheeled walker (72.26 seconds vs 82.93 seconds, $p=0.001)$. The opposite was observed in this study where the differences were found between the fixed walker and the four-wheeled walker and the two-wheeled walker and the four-wheeled walker, revealing a gait speed higher with the four-wheeled walker that with the other two walkers. However, this author alerts us to the fact that the studies available in the literature focus on healthy individuals and not on older people.

In this study, the differences were also not significant in the energy cost between the three walkers and in the final HR, which contradicts the results found by Edelstein (2013) who reported that the HR and the oxygen uptake increase considerably in users of four-tip walkers when compared to users of articulated walkers. However, this study was performed in a laboratory and not in the field as the study presented here. 
The following are important limitations of this study: the small and non-probability sample, which makes it difficult to generalize the results; the lack of assessment of users' cognitive skills, which may have interfered with the older person's functional capacity; the lack of a control group; difficulties related to the participants' adaptation to the different types of walkers, such as the lack of experience in using another type of walker; the heterogeneity of comorbidities and the physical and mental characteristics of the sampled participants. All of them should be considered in future studies. Moreover, another limitation was that the data in the data collection tool were collected by the main researcher because it was not possible for an unbiased collaborator to participate in the implementation of the tasks listed in the protocol, which posed limitations to its internal validity as it raised doubts related to whether the results resulted exclusively from the type of walker used. As to external validity, it is compromised by the small sample size and the sampling method.

The EEER should develop the necessary skills for a correct assessment of older people's functionality so as to be able to diagnose their mobility limitations and disabilities and intervene in the promotion of their adaptation and independence through the use and prescription of the most suitable assistive gait devices, whenever necessary (Regulamento n. ${ }^{\circ} 125 / 2011$ de 18 de fevereiro, 2011). In addition, it should be noted that, given the high percentage of family members prescribing walkers in this sample ( $n$ $=14 ; 35.0 \%$ ), the EEER should educate this population to prevent the occurrence of adverse events related to the use of unsuitable assistive devices, by using the most appropriate teaching strategies and supervising the correct use of walkers by users and caregivers (Regulamento n. ${ }^{\circ} 350 / 2015$ de 22 de junho, 2015).

\section{Conclusion}

Walkers are assistive gait devices which seek to enhance older people's functionality through the promotion of a more stable gait. A detailed analysis of the functional performance profile allows prescribing the most appropriate walker to their needs and to a safer ambulation, and it is part of rehabilitation nursing care.

In the aging process, falls are considered one of the major public health issues. This phenomenon is usually associated with the functional decline, namely decreased strength, muscle mass, and gait speed, as well as with changes in postural balance as a result of a deterioration of vision and the vestibular and somatosensory system, which affect older people's functional performance profile while walking. During older people's institutionalization, this situation can worsen, with implications in both their independence and quality of life.

In this study, differences were found between the three types of walkers in the total time and the gait speed. The differences showed that the total time with the fixed walker is lower than with the two-wheeled walker and that the total time with the four-wheeled walker is lower than with the two-wheeled walker.

Gait speed is higher with the four-wheeled walker than with the fixed walker and with the two-wheeled walker, but the gait speed with the two-wheeled walker is lower than with the fixed walker. Therefore, the functional performance profile is faster with the four-wheeled walker than with the other two options but slower with the two-wheeled walker than with the fixed walker.

Although these data cannot be generalized to the general population, they should be taken into account in clinical practice because there are different types of walkers and their selection and prescription should be based on an individualized assessment of the user's functional abilities to achieve a more effective and safer use of this device and, consequently, reduce the risk of falling.

Given the proximity, the potential for intervention, and the skills of EEER, we recommend the development of an electronic platform that can integrate knowledge about the new technologies in their training and include technical information about the walking aids available on the market. This platform can help to select the most appropriate device based on an analysis of the user's functional performance profile, as well as educate family members on the use and acquisition of the best device for the older person's difficulties and disabilities, preventing the occurrence of adverse events such as falls. The development of this platform will contribute to 
a safer functional performance that promotes maximum independence among older people. Thus, future studies should be conducted in different contexts and with other key parameters such as effectiveness, cost, operability, and reliability, which can be integrated into a technological platform and allow for a more detailed, practical, and objective analysis of this type of devices, with the ultimate purpose of selecting and prescribing the best assistive gait device for each person.

\section{Funding}

This study is integrated into the research project MIND\&GAIT - Promoting independent living in frail older adults by improving cognition and gait ability and using assistive products. The project (reference POCI-01-0145-FEDER-023822) is co-funded by the program COMPETE2020 under the Incentive System for Research and Technological Development, with an incentive from the European Regional Development Fund (ERDF).

\section{References}

Braun, T., Marks, D., Zutter, D., \& Grüneberg, C. (2015). The impact of rollator loading on gait and fall risk in neurorehabilitation: A pilot study. Disability and Rehabilitation: Assistive Technology, 10(6), 475-481. doi:10.3109/17483107.2014.926568

Cetin, E., Muzembo, J., Pardessus, V., Puisieux, F., \& Thevenon, A. (2010). Impact of different types of walking aids on the physiological energy cost during gait for elderly individuals with several pathologies and dependent on a technical aid for walking. Annals of Physical and Rehabilitation Medicine, 53(6), 399405, doi:10.1016/j.rehab.2010.06.003

Edelstein, J. E. (2013). Assistive devices for ambulation. Physical Medicine and Rehabilitation Clinics of North América, 24(2), 291-303. doi:10.1016/j. pmr.2012.11.001

Instituto Nacional de Estatística. (2017). Disponível em Maio de 2017. Nível de escolaridade. Retrieved from http://smi.ine.pt/Conceito/Detalhes/3294

Lobo, A. J. (2012). Relação entre aptidão física, atividade física e estabilidade postural. Revista de Enfermagem
Referência, 3(7), 123-130. doi:10.12707/RIII1181

Maria, E. C., \& Rodrigues, S. (2009). Quedas no senescente: Equilíbrio e medo de cair. Revista da Faculdade de Ciências da Saúde, 6, 162-172. Retrieved from https://core.ac.uk/download/pdf/61007900.pdf

Mota de Sousa, L. M., Marques-Vieira, C. M., Caldevilla, M. N., Henriques, C. M., Severino, S., \& Caldeira, S. M. (2016). Risco de quedas em idosos residentes na comunidade: revisão sistemática da literatura. Revista Gaúcha de Enfermagem, 37(4). doi: 10.1590/19831447.2016.04.55030.

Parreira, P. (2013). Processo empreendedor: Da ideia ao protótipo. Coimbra, Portugal: Escola Superior de Enfermagem de Coimbra.

Poier, P. H. (2013). Avaliação da oscilação corporal e marcha de idosos com a utilização de um andador com suporte de tronco desenvolvido na UTFPR (Master's dissertation). Universidade Tecnológica Federal do Paraná, Brasil. Retrieved from http://repositorio.utfpr.edu.br/jspui/ bitstream/1/744/1/CT_PPGEB_M_Poier\%2c\%20 Paloma\%20Hohmann_2013.pdf

Regulamento n. ${ }^{\circ}$ 125/2011 de 18 de Fevereiro. Diário da Républica no 35/2011 - II Série. Ordem dos Enfermeiros. Lisboa, Portugal. Retrieved from https://www. ordemenfermeiros.pt/arquivo/legislacao/Documents/ LegislacaoOE/Regulamento\%20125_2011_CompetenciasEspecifEnfreabilitacao.pdf

Regulamento n. ${ }^{\circ}$ 350/2015 de 22 de Junho. Diário da República no 119/2015 - 2. a série. Ordem dos Enfermeiros. Lisboa, Portugal. Retrieved from https://dre. pt/home/-/dre/67552234/details/maximized

Silva, L. F. (2012). Projeto, desenvolvimento e implementação de um "guiador" num andarilho motorizado (Master's dissertation). Universidade do Minho, Escola de Engenharia, Portugal.

Sousa, A., Martins, C., Silva, J., Santos, S., Tavares, J., \& Henriques, E. (2014). Cuidado restaurativo: Uma nova filosofia no cuidado às pessoas idosas. Journal of Aging \& Inovation, 3(2), 36-49. Retrieved from http:// www.journalofagingandinnovation.org/wp-content/ uploads/4-cuidado-restaurativo.pdf

Teresa, A. M. (2014). Estudo e avaliação da adaptação andarilho-doença do utilizador (Master's dissertation). Universidade do Minho, Escola de Engenharia, Portugal.

Van Hook, F. W., Demonbreun, D., \& Weiss, B. D. (2003). Ambulatory devices for chronic gait disorders in the elderly. American Family Physician, 67(8), 1717-1724. Retrieved from https://www.aafp.org/ afp/2003/0415/p1717.html 
